\title{
A Note on the Montessori of Ethnobiology, Hal Conklin
}

\author{
Myrdene Anderson $^{1^{*}}$ \\ ${ }^{1}$ Department of Anthropology and Program in Linguistics, Purdue University, West Lafayette, IN, USA. \\ *myanders@purdue.edu
}

Received July 3, 2016

OPEN ӘACCESS

Accepted September 14, 2016

DOI 10.14237/ebl.7.2.2016.738

Copyright (c) 2016 by the author(s); licensee Society of Ethnobiology. This is an open-access article distributed under the terms of the Creative Commons Attribution-NonCommercial 4.0 International Public License (https://creativecommons.org/licenses/by-nc/4.0), which permits non-commercial use, distribution, and reproduction in any medium, provided the original author and source are credited.

With the passing of Harold C. Conklin in February of 2016, many feel the loss of this foundational figure in ethnobiology while continuing to celebrate his accomplishments. I also miss him as a teacher, a person who eagerly shared his wisdom, hunches, and feelings with anyone in reach.

For me, Hal remains a teacher rather than a mentor. I seem to recall that Hal bristled at the use of that now trendy term, an aversion that I came to share. Ironically, a couple of years ago I agreed to submit a manuscript featuring Hal for a volume to be entitled Mentors and Mentoring in the Arts, Humanities, and the Social Sciences, edited by Frank A. Salamone and Marjorie Snipes. Partly given my ambivalence around the M-word, that manuscript bogged down and was not submitted until the very final deadline at the end of October 2015. I believe I sent a copy to $\mathrm{Hal}$, but since it was not acknowledged, I am not so sure; in fact, I believe I got cold feet imagining his critical eye, even if hopefully tempered by indulgent amusement.

My title said it all: "Harold C. Conklin: The joy of ethnography-from eye to ear to mouth to hand, and beyond to within and without." Given that still forthcoming essay, I can be brief here. Hal did not like attention drawn to himself, and quite emphatically discouraged any formal Festschrift. Only by working behind his back and with the help of Jean Conklin was I able to organize a symposium honoring him at the AAA meetings in 1991.

In the seminar room at Yale or out in the natural and cultural world that was his oyster, Hal exuded observations about things near and far, about ideas recent or distant, and about sensations of the moment. No doubt endowed with more than the ordinary five senses, even more than seven plus-or- minus two of them, Hal welcomed sensations as indulgences even when they did not contribute to a task at hand, discriminating one specimen from another, for instance. One entire section of his threesection Folk Classification bibliography (Conklin 1980) was devoted to the ephemeral, and one of the three subsections of this, to color (the other two to sensation and orientation in space and time). It is no opportunistic accident that Hal submitted Hanunoo color to analysis, to be shared so generously with wider publics.

Knowing Hal's penchant for color excused my own fieldwork experiments with plant dyeing during my initial fieldwork in Norwegian Lapland from 1971 to 1976. This entailed expanding the ethnobotanical inventory I had initially imagined to be the scope of my investigations - specifically lichens as a limiting resource for reindeer in winters. Despite the Saami themselves evincing little interest in plants (they are not motile, after all) or color (other than the imported aniline-dyed textiles of their "traditional" outfits). I persevered, despite being judged by Saami friends as both silly and lazy, avoiding worthwhile tasks. Eventually I had 700 samples of colored yarn. How to share, or use, this ethnographic by-product, though, could be an issue, as there was little justification for it, let alone ethnographic documentation (other than remarks like, Can't you get red, can't you get blue?).

But, aside from plants and color, Hal was also an enthusiast of technologies, of how people built things of any size or shape or utility (a given, I guess), which then he could artfully reconstruct in scale models. He would enter every seminar like a confident juggler, laden with stacks of volumes, sheaves of specimens, and assemblies of scale models. So I would need to expand my ethnographic expertise in the direction of mastering more legitimately authentic Saami skills. 
With that in mind, I apprenticed myself to one of the few individuals making a living from handicrafts - these of reindeer antler, bone, and sinew, and of burls from birch and of pewter thread. Starting from scratch, even manufacturing my own tools, I fashioned a handloom otherwise for the weaving of belts and boot straps. With this, I designed a necktie for $\mathrm{Hal}$; it was a narrow one, with an even narrower stretch for around the neck. I selected the rarest of colors, the most precious a baby blue from bluebells, others greens, yellows, and tans. Even though I had no model, the result appeared to be what I had intended, a tie, and I sent it off to Hal. On this contribution to scholarship I received no editing, only thanks and a passel of queries about every aspect of the project. Since then, during the 1980s right to my last visit with him in New Haven in 2011 and up to his last AAA conference around 2013, whenever Hal could anticipate seeing me, he would be wearing that tie!

Hal's style of teaching was not a premeditated pedagogy, he just shared himself. On the one hand he emphasized the value in letting oneself be surprised by data, any and all of it. On the other hand, it was documentation-documentation-documentation, all the way down, up, back, and around. In that process, I will admit that wild data become tamer, domesticated, and locatable capta. I don't recall witnessing Hal ever searching for anything; it was as though his Innenwelt perfectly matched his personal and scientific Umwelt.

In the service of this ideal, Hal would avail himself of every trick of the trade, these tools and toys always eagerly promoted with his students as well, who sometimes had to be enlisted to test products or find sources. There was a complicated time-date-serial numbering stamping implement, larger and much heavier than an egg-beater. Hal thought every document, every specimen, had to be clearly marked as to time, place, and identity, this nuanced by as many informant voices as possible. And each category of data/capta, each roll of film, each tape, must be separately logged; don't forget the time of day, or else one will have to infer that from shadows, and don't forget to annotate with any abductions of the moment, about that ambient noise, the smudges and kludges of fieldwork.

Another contraption that Hal imagined would eventually be appreciated by all of us students was a rolling extension ladder that could be situated to access every top shelf in a library or storeroom. Hal himself researched the most perfect product, something he needed in the countless number of spaces he colonized in the several buildings of the anthropology department and then also in the nearby Peabody Museum.

When it came to writing instruments, Hal opted for permanent ink or a lead pencil. For the first bout of fieldwork for the dissertation, still in thrall of Hal, and given the arctic setting, I had to sleep not only with the batteries for camera and tape-recorder, but also with my rapidograph and India ink, to keep everything thawed.

When it came to paper, well, this would not be an opinion, but a fact. It happened that Merriam-Webster relied on Hal for some of its specialized dictionary entries having to do with botany and the Philippines. He would periodically receive drawers of 3 by 5 -inch cards for the terms in question-but they were not cards, they were slips of paper. Some were dated many decades in the past, conceivably even more than a century, but still crisp with erect corners. Even though I selected Yale's department of anthropology in 1968 largely because of Hal, I would not get to meet him until his return from the field in Ifugao until 1969. That would be the earliest that I became aware of the importance of the correct paper.

In Hal's methods course, we were all introduced to a particular paper that would be worthy of all our data collection; it was the paper he had discovered from Merriam-Webster's filing system, and could be ordered in many sizes from Judd Paper Company in Holyoke, Massachusetts. About this time or the following year, however, Judd Paper Company let their best customer besides Merriam-Webster know that they would be replacing this paper type with an equivalent one bearing a different label. MerriamWebster had beaten Hal Conklin to the draw, securing the final warehouse-full for themselves. Hal was seriously concerned; after all, nothing could be exactly the same, even with the same label, and this label had changed, perhaps from Edgemont to Greenwood or vice-versa, or maybe Edgewood to Greenmont, or vice-versa (Hal would not tolerate such imprecision, but the internet has not been helpful in this detail).

Students already had a tradition of combining their paper orders so as to avail themselves of a price discount at $68,000 \ldots$ of the 3 by 5 -inch slips (I still have some of my quota). They arrived in flat, rectangular clumps of about 2,000, wrapped in plain brown paper. The next step in Hal's course was an empirical 
test of the properties of this already-deemed-perfect paper, according to our anticipated field conditions. But now, we had two species of paper product to test, rather than just the one. In addition, we always had to also involve a variety of writing instruments, just to demonstrate the obvious, that some would not be indelible, and even some that were, might not outlast our own limited lifetimes.

For subsets of their experimental scribbles, some students simulated the Amazon rainforest with different cycles of washing machines, or for realistic wear-and-tear, kept some slips in pockets with loose change, and I recall stuffing a bunch in a snowbank for the winter. At the end of the semester, we put our evidence together and admitted that a ball-point pen would not be suitable in the field, but a 2.75 lead pencil might be, only to be trumped by a fine-pointed rapidograph pen. Between the Edgewood and Greenmont paper, however, it was a draw. I detected that this was a disappointment for Hal, that he would have been more satisfied with a difference in either direction. He did, however, hold an ace, that in personal connections. He always had personal connections: many would be his interlocutors on the phone, day and night, covering every earthly timezone.

In this case, his friend was a new curator of paper, no less, at the recently opened Yale museum for British art. The good curator had kilns for this very purpose. Hal contributed the paper samples, blind, and in return was assured, that all the way to a simulated period of 500 years, the two paper types were equivalent, in fact, indistinguishable. This is an example of $\mathrm{Hal}$ just not letting go-an inspiration for others that seldom can be equaled.

One reason the writing of this brief note has been so intimidating, is the example $\mathrm{Hal}$ set in everything he tackled. When Floyd Lounsbury, his own mentor and eventual colleague of half a century died, Hal embarked on one more ethnographic project, to document his friend, from birth onwards, even visiting Wisconsin. To do so for Hal would also be a fitting task for scholars down the line.

At this moment, it will suffice to recognize Hal's contributions to our minds and styles of inquiry. When I first read his work before coming to Yale, I thought of him as an ethnobotanist, then later as an ethnobiologist, finally as an ethnoecologist. And reviewing the diversity amongst his students' research topics then and now ongoing, one might conclude that even ethnoecology will not exhaustively represent the breadth and depth of Hal's fascination with the world.

\section{References Cited}

Conklin, H. C. 1980. Folk Classification: A Topicallyarranged Bibliography of Contemporary and Background References through 1971. Department of Anthropology, Yale University, New Haven, CT. 